\title{
INDEX TO Volume 26 (2008)
}

\section{Articles}

BAUBEROT, Arnaud. Un projet de réforme hygiènique des modes de vie: naturistes et végétariens à la Belle Époque (Vol. 26, No. 3, 1)

CHATRIOT, Alain. La difficile écriture de l'histoire du Conseil d'État (Vol. 26, No. 3, 23)

FETTE, Julie. Apology and the Past in Contemporary France (Vol. 26, No. 2, 78)

FORBES, Amy Wiese. The Lithographic Conspiracy: How Satire Framed Liberal Political Debate in Nineteenth-Century France (Vol. 26, No. 2, 16)

GODELIER, Éric. La naissance d'un géant: Arcelor-Mittal (1948-2006) (Vol. 26, No. 2, 114)

GOLDHAMMER, Arthur. A Brief Comment on Nancy Green's Essay (Vol. 26, No. 2, 13)

GREEN, Nancy. Tocqueville, Comparative History and Immigration in Two Democracies (Vol. 26, No. 2, 1)

LIKIN, Max. "Nothing Fails Like Success": The Marxism of Raymond Aron (Vol. 26, No. 3, 43)

NEWSOME, W. Brian. Paul-Henry Chombart de Lauwe: Catholicism, Social Science, and Democratic Planning (Vol. 26, No. 3, 61)

REID, Donald. Pierre Goldman: From Souvenirs obscurs to Lieu de mémoire (Vol. 26, No. 2, 51)

SPECIAL ISSUE : French Color-Blindness in Perspective: The Controversy Over "Statistiques Ethniques"

BLUM, Alain and GUÉRIN-PACE, France. From Measuring Integration to Fighting Discrimination: The Illusion of "Ethnic Statistics" (Vol. 26, No. 1, 45)

SABBAGH, Daniel and PEER, Shanny. Introduction (Vol. 26, No. 1, 1)

SIMON, Patrick. The Choice of Ignorance: The Debate on Ethnic and Racial Statistics in France (Vol. 26, No. 1, 7)

TIN, Louis-Georges. Who is Afraid of Blacks in France? The Black Question: The Name Taboo, the Number Taboo (Vol. 26, No. 1, 32) 
DOSSIER: LaḮITÉ, PART III

DIMIER, Véronique. French Secularism in Debate: Old Wine in New Bottles (Vol. 26, No. 1, 92)

VICHNIAC, Judith. Jewish Identity Politics and the Scarf Affairs in France (Vol. 26, No. 1, 111)

ZUBER, Valentine. La séparation des Églises et de l'État en France et à Genève (1905-1907): Une solution pour deux histoires (Vol. 26, No. 1, 71)

FORUM: Nicolas Jabko's Playing the Market

DOBBIN, Frank. Integrating Paradigms (Vol. 26, No.3, 94)

JABKO, Nicolas. A Response to My Critics (Vol. 26, No. 3, 105)

PHILIPPON, Thomas. Economics and Playing the Market (Vol. 26, No. 3, 102)

VERDUN, Amy. Strategy, Ideas and Political Leadership (Vol. 26, No. 3, 98)

ZUBER, Martha. Introduction (Vol. 26, No. 3, 92)

\section{Review Essays}

CHRISTOFFERSON, Michael Scott. The French "Sixties" (Vol. 26, No. 3, 123)

DWYER, Philip. Remembering and Forgetting in Contemporary France: Napoleon, Slavery, and the French History Wars (Vol. 26, No. 3, 110)

\section{Book Reviews}

BOUDIC, Goulven. Intellectuels Communistes: Essai sur l'obéissance politique, "La Nouvelle critique», 1967-1980 by Frédérique Matonti (Vol. 26, No. 1, 143)

CHATRIOT, Alain. Une fiscalité pour la croissance: La Direction Générale des Impôts et la politique fiscale en France de 1948 à la fin des années 1960 by Frédéric Tristram (Vol. 26, No. 2, 143)

CHRISTOFFERSON, Michael. The Specter of Democracy by Dick Howard (Vol. 26, No. 1, 148)

GOLLAIN, Françoise. Une sécurité d'emploi ou de formation by Paul Boccara (Vol. 26, No. 1, 150)

COLE, Joshua. The Invention of Decolonization: The Algerian War and the Remaking of France by Todd Shepard (Vol. 26, No. 1, 137)

DARMON, Muriel. Le Lien social by Pierre Bouvier (Vol. 26, No. 3, 145)

DAUGHTON, James P. Divided Houses: Religion and Gender in Modern France by Caroline Ford (Vol. 26, No. 1, 133)

DISALVO, Daniel. L'Extrême Gauche plurielle: Entre démocratie radicale et révolution by Philippe Raynaud (Vol. 26, No. 2, 146)

FORD, Caroline. Curing the Colonizers: Hydrotherapy, Climatology, and French Colonial Spas by Eric T. Jennings (Vol. 26, No. 2, 140) 
GOLSAN, Richard J. A Holocaust Controversy: The Treblinka Affair in Postwar France by Samuel Moyn (Vol. 26, No. 1, 139)

HARGREAVES, Alec G. Integrating Islam: Political and Religious Challenges in Contemporary France by Jonathan Laurence and Justin Vaïsse (Vol. 26, No. 3, 148)

HEUER, Jennifer. From the Salon to the Schoolroom: Educating Bourgeois Girls in Nineteenth-Century France by Rebecca Rogers (Vol. 26, No. 3, 141)

KRAMER, Lloyd. The Post-Revolutionary Self: Politics and Psyche in France, 1750-1850 by Jan Goldstein (Vol. 26, No. 1, 129)

MOODIE, Benjamin. Le Deuxième Âge de l'émancipation: La société, les femmes et l'emploi by Dominique Méda and Hélène Périvier (Vol. 26, No. 1, 153)

MURPHY, Jack. Liberté, égalité, carte d'identité: Les jeunes issus de l'immigration et l'appartenance nationale by Évelyne Ribert (Vol. 26, No. 2, 149)

POPIEL, Jennifer J. The Family and the Nation: Gender and Citizenship in Revolutionary France, 1789-1830 by Jennifer Ngaire Heuer (Vol. 26, No. 2, 137)

WHITE, Owen. Native Sons: West African Veterans and France in the Twentieth Century by Gregory Mann (Vol. 26, No. 3, 143)

\section{INDEX OF BOOKS REVIEWED}

BOUVIER, Pierre. Le Lien social reviewed by Muriel Darmon (Vol. 26, No. 3, 145)

FORD, Caroline. Divided Houses: Religion and Gender in Modern France reviewed by James P. Daughton (Vol. 26, No. 1, 133)

GOLDSTEIN, Jan. The Post-Revolutionary Self: Politics and Psyche in France, 1750-1850 reviewed by Lloyd Kramer (Vol. 26, No. 1, 129)

HOWARD, Dick. The Specter of Democracy reviewed by Michael Christofferson (Vol. 26, No. 1, 148)

BOCCARA, Paul. Une sécurité d'emploi ou de formation reviewed by Françoise Gollain (Vol. 26, No. 1, 150)

JENNINGS, Eric T. Curing the Colonizers: Hydrotherapy, Climatology, and French Colonial Spas reviewed by Caroline Ford (Vol. 26, No. 2, 140)

LAURENCE, Jonathan and VAÏSSE, Justin. Integrating Islam: Political and Religious Challenges in Contemporary France reviewed by Alec G. Hargreaves (Vol. 26, No. 3, 148)

MANN, Gregory. Native Sons: West African Veterans and France in the Twentieth Century reviewed by Owen White (Vol. 26, No. 3, 143)

MATONTI, Frédérique. Intellectuels Communistes: Essai sur l'obéissance politique, "La Nouvelle critique », 1967-1980 reviewed by Goulven Boudic (Vol. 26, No. 1, 143)

MÉDA Dominique and PÉRIVIER Hélène Le Deuxième Âge de l'émancipation: La société, les femmes et l'emploi reviewed by Benjamin Moodie (Vol. 26, No. 1, 153) 
MOYN, Samuel. A Holocaust Controversy: The Treblinka Affair in Postwar France reviewed by Richard J. Golsan (Vol. 26, No. 1, 139)

NGAIRE HEUER, Jennifer. The Family and the Nation: Gender and Citizenship in Revolutionary France, 1789-1830 reviewed by Jennifer J. Popiel (Vol. 26, No. 2, 137)

RAYNAUD, Philippe. L'Extrême Gauche plurielle: Entre démocratie radicale et révolution reviewed by Daniel DiSalvo (Vol. 26, No. 2, 146)

RIBERT, Évelyne. Liberté, égalité, carte d'identité: Les jeunes issus de l'immigration et l'appartenance nationale reviewed by Jack Murphy (Vol. 26, No.2, 149)

ROGERS, Rebecca. From the Salon to the Schoolroom: Educating Bourgeois Girls in Nineteenth-Century France reviewed by Jennifer Heuer (Vol. 26, No. 3, 141)

SHEPARD, Todd. The Invention of Decolonization: The Algerian War and the Remaking of France reviewed by Joshua Cole (Vol. 26, No. 1, 137)

TRISTRAM, Frédéric. Une fiscalité pour la croissance: La Direction Générale des Impôts et la politique fiscale en France de 1948 à la fin des années 1960 reviewed by Alain Chatriot (Vol. 26, No. 2, 143) 